\title{
Arsenic in drinking water in the Los Altos de Jalisco region of Mexico
}

\author{
Roberto Hurtado-Jiménez ${ }^{1}$ and Jorge L. Gardea-Torresdey ${ }^{2}$
}

Suggested citation

Hurtado-Jiménez R, Gardea-Torresdey JL. Arsenic in drinking water in the Los Altos de Jalisco region of Mexico. Rev Panam Salud Publica. 2006;20(4):236-47.

\begin{abstract}
Objective. To establish the degree of contamination by arsenic in drinking water in the Los Altos de Jalisco (LAJ) region of west-central Mexico, and to estimate the levels of exposure that residents of the area face.

Methods. Total arsenic concentration (the sum of all arsenic forms, organic and inorganic) was determined for 129 public water wells in 17 municipal capitals (cabeceras municipales) of the LAJ region, using inductively coupled plasma-optical emission spectroscopy. For most of the wells, water samples were taken in both November 2002 and October 2003. The levels of exposure to arsenic were estimated for babies (10 kg), children (20 kg), and adults (70 kg). Results. Mean concentrations of arsenic higher than the Mexican national guideline value of $25 \mu \mathrm{g} / \mathrm{L}$ were found in $44(34 \%)$ of the 129 wells. The mean concentration of total arsenic for the 129 wells ranged from $14.7 \mu \mathrm{g} / \mathrm{L}$ to $101.9 \mu \mathrm{g} / \mathrm{L}$. The highest concentrations were found in well water samples collected in the cities of Mexticacán $(262.9 \mu \mathrm{g} / \mathrm{L})$, Teocaltiche $(157.7$ $\mu \mathrm{g} / \mathrm{L})$, and San Juan de los Lagos $(113.8 \mu \mathrm{g} / \mathrm{L})$. Considering the global mean concentration for all the wells in each of the 17 cities, the mean concentration of arsenic exceeded the Mexican guideline value in 7 of the cities. However, the global mean concentration in all 17 cities was higher than the World Health Organization guideline value of $10 \mu \mathrm{g} / \mathrm{L}$ for arsenic. The range of the estimated exposure doses to arsenic in drinking water was 1.1-7.6 $\mu \mathrm{g} / \mathrm{kg} / \mathrm{d}$ for babies, $0.7-5.1 \mu \mathrm{g} / \mathrm{kg} / \mathrm{d}$ for children, and $0.4-2.7 \mu \mathrm{g} / \mathrm{kg} / \mathrm{d}$ for adults.

Conclusions. At the exposure doses estimated in the LAJ region, the potential health effects from chronic arsenic ingestion include skin diseases, gastrointestinal effects, neurological damage, cardiovascular problems, and hematological effects. While all the residents may not be affected, an important fraction of the total population of the LAJ region is under potential health risk due to the ingestion of high levels of arsenic. Epidemiological studies to determine the arsenic levels in the blood, hair, and nails of humans should be conducted in the LAJ region to help assess the relationship between the prevalence of health problems and the chronic ingestion of arsenic.
\end{abstract}

Key words Arsenic, water supply, water pollutants, Mexico.
1 El Colegio de la Frontera Norte, A.C., Ciudad Juárez, Chihuahua, México. Send correspondence to: Roberto Hurtado-Jiménez, Ave. Insurgentes No. 3708, Fracc. Los Nogales, CP 32350, Ciudad Juárez, Chihuahua, México; telephone: 52656 6168578; fax: 52656 6169214; e-mail: rhurtado@colef.mx

2 University of Texas at El Paso, Department of Chemistry and the Environmental Science and Engineering Ph.D. Program, University of Texas at El Paso, El Paso, Texas 79925, United States of America.
The Los Altos de Jalisco (Highlands of Jalisco) region is made up of a group of 20 municipalities (municipios) located in the northeastern part of Jalisco, a state located in west-central Mexico (Figure 1 and Figure 2). The Los Altos de Jalisco (LAJ) region has a population around 665000 inhabitants, and has an area of $16440.69 \mathrm{~km}^{2}$ (1). The LAJ region belongs to the Trans-Mexican Volcanic Belt, an active volcanic area that exhibits intense hydrothermal activity, as evidenced by hot springs, fumaroles, and geysers. 
FIGURE 1. Location of the state of Jalisco, the Los Altos de Jalisco region, and the TransMexican Volcanic Belt in Mexico

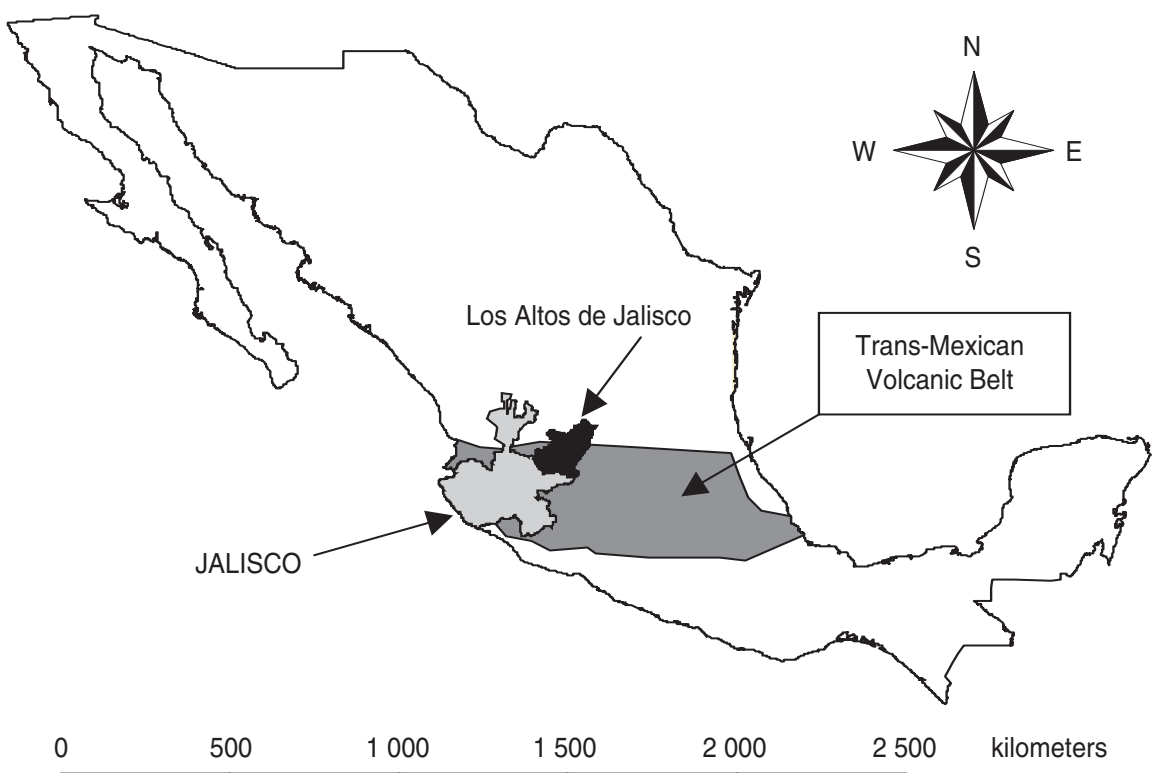

FIGURE 2. Location of municipalities in the Los Altos de Jalisco region of Mexico ${ }^{a}$
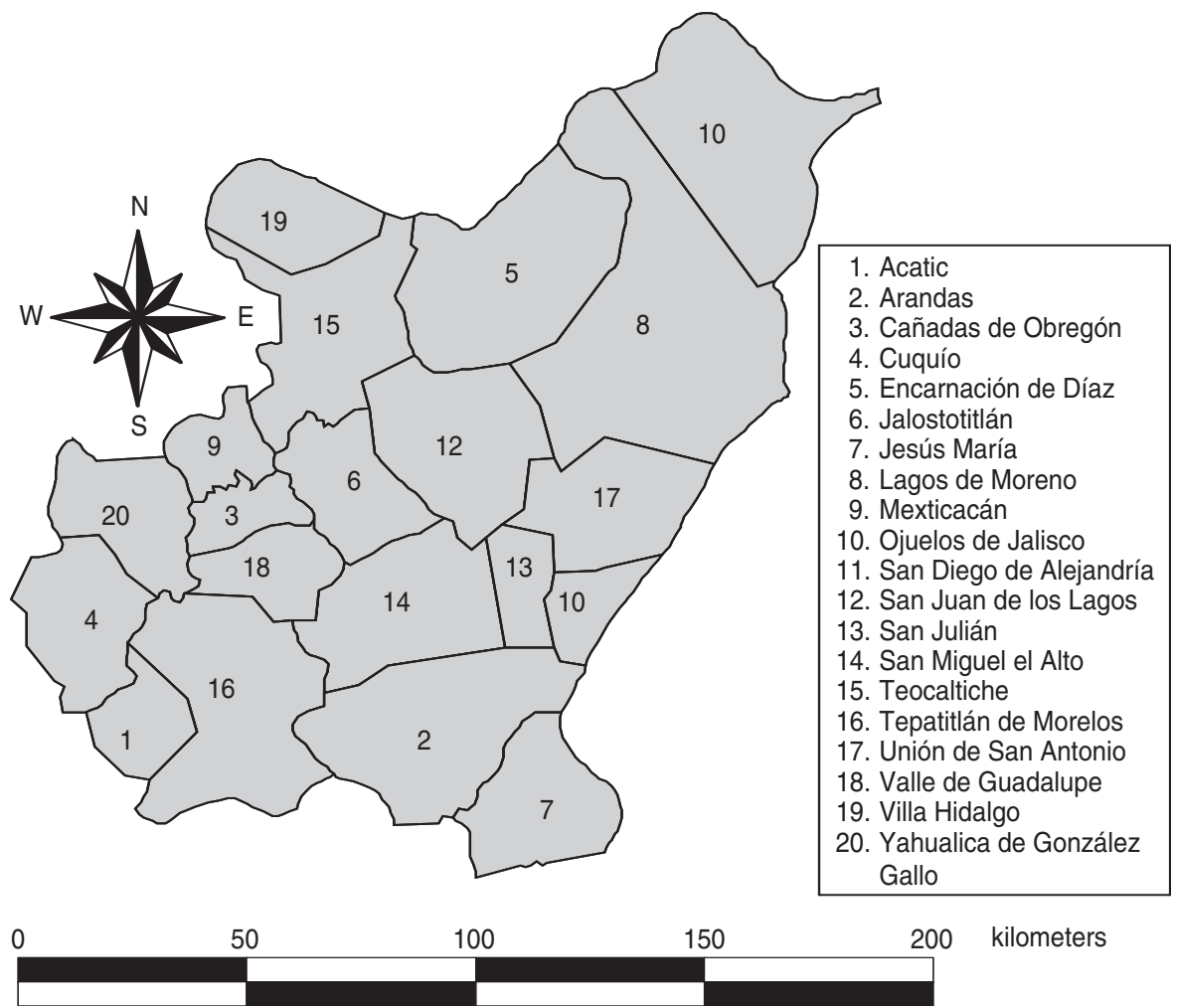

a In this study, chemical analyses for three municipal capitals (Cañadas de Obregón (3), Cuquío (4), and Yahualica de González Gallo (20)) were not performed because their water supply comes only from surface water.
Consequently, underground aquifers located in the Trans-Mexican Volcanic Belt have a high probability of being contaminated with toxic elements $(2,3)$. It is well known that thermal waters contain high levels of heavy metals and trace elements. One of these elements is arsenic, whose toxicity has been recognized since ancient times.

Arsenic is a naturally occurring chemical element that is widely distributed in the earth's crust. It occurs in several forms, often combined with other chemical elements. When arsenic is combined with oxygen, chlorine, and sulfur, it is known as inorganic arsenic. Arsenic combines with carbon and hydrogen to form organic arsenic compounds. In general, inorganic arsenic is more dangerous than is organic arsenic (4). Inorganic arsenic predominates in underground aquifers.

Arsenic minerals can be found in a variety of geological environments, including igneous, sedimentary, and metamorphic rocks (5). Many arsenic minerals may be found at trace levels in practically all living matter (6). Other sources of arsenic include volcanic gases and geothermal waters (7).

The arsenic concentrations in natural waters around the world range from $<0.5$ to $5000 \mu \mathrm{g} / \mathrm{L}$. However, the typical concentrations in most countries are of less than $10 \mu \mathrm{g} / \mathrm{L}$, and sometimes substantially lower (less than $1 \mu \mathrm{g} / \mathrm{L})(8)$. High arsenic concentrations occur in a variety of environments, including both oxidizing (high $\mathrm{pH}$ ) and reducing aquifers (9).

Arsenic contamination of drinking water supplies can result from natural or artificial processes. Natural contamination generally comes mainly from mineral deposits or geothermal fluids. The main sources of artificial or anthropogenic contamination are usually associated with industrial applications such as wood preservation, petroleum refining, semiconductor manufacturing, production of nonferrous alloys (principally lead alloys used in leadacid batteries), burning of fossil fuels (especially coal), metal production (such as gold), agricultural applications (pesticides and feed additives), and irrigation with polluted waters $(4,10-12)$. 
Mexico's current national guideline value for arsenic in water delivered to the public water system was recently set at $25 \mu \mathrm{g} / \mathrm{L}(13)$. In 1993 the World Health Organization (WHO) set $10 \mu \mathrm{g} / \mathrm{L}$ as the guideline value for arsenic in drinking water (14). In the United States of America the current standard, or maximum contaminant level, for arsenic in drinking water is $50 \mu \mathrm{g} / \mathrm{L}$, which was set in 1975. Nevertheless, a new standard $(10 \mu \mathrm{g} / \mathrm{L})$ was promulgated in 2001 by the Environmental Protection Agency (EPA) of the United States. Water systems were supposed to start complying with the new EPA standard by January 2006 (15).

The occurrence of arsenic in drinking waters has been reported in various countries, including Argentina, Austria, Bangladesh, Chile, China, Ghana, Greece, Hungary, India, Mexico, Romania, South Africa, Taiwan, Thailand, and the United States (16).

In Mexico there are several areas where high levels of arsenic in groundwater have been reported. The four most important areas are: (1) Comarca Lagunera (a region of 15 municipalities located in the north-central part of Mexico, 5 in the state of Coahuila and 10 in the state of Durango), where the total arsenic concentration (the sum of all arsenic forms, organic or inorganic) in well waters has ranged from 7 to $740 \mu \mathrm{g} / \mathrm{L}$ (17); (2) Valle del Guadiana (located in the state of Durango, in the north-central part of Mexico), with arsenic concentrations in the range of 5 to $167 \mu \mathrm{g} / \mathrm{L}$ (18); (3) Valle de Zimapán (in the state of Hidalgo, in central Mexico), where the concentration of arsenic in 32 groundwater samples has ranged from 14 to $1097 \mu \mathrm{g} / \mathrm{L}$ (the highest value was found in the water pumped from one of the most productive wells) (19); and (4) the city of Hermosillo (in the state of Sonora, in northern Mexico), with arsenic concentrations up to $305 \mu \mathrm{g} / \mathrm{L}$ (20).

It is well known that chronic exposure to high levels of arsenic causes a wide variety of serious human health problems. These problems include dermal changes (pigmentation, hyperkeratosis, and ulceration), gastrointestinal effects (stomach pain, nausea, vomiting, and diarrhea), neurological damage, cardiovascular problems (high blood pressure, heart attack, and stroke), various types of cancer (skin, bladder, lung, kidney, and other organs), and respiratory, pulmonary, hematological, hepatic, renal, developmental, reproductive, immunological, genotoxic, and mutagenetic effects $(4,9,16,21)$.

The three aims of this study were: (1) to determine the levels of arsenic in the public water wells located in the LAJ municipal capitals (cabeceras municipales), (2) to report the distribution of arsenic in the groundwaters in the region, and (3) to estimate the levels of the arsenic exposure via drinking water that residents of the LAJ region face. (The municipal capital is the city or town where the municipality's administrative offices are located. In general, the city or town with the largest population among the communities in the municipality is the municipal capital. The municipality and the municipal capital usually have the same name.)

\section{MATERIALS AND METHODS}

\section{Sampling}

In order to determine the level of arsenic in the groundwater aquifers located in the LAJ region, water samples were collected from 129 public wells in 17 of the LAJ region's 20 municipal capitals. In this study, arsenic concentrations were determined in groundwater samples only. There are three LAJ municipal capitals (Cañadas de Obregón, Cuquío, and Yahualica de González Gallo) where surface water is the only source of water, and so we did not take samples in those three locations. (A preliminary study carried out by the authors (not published) showed that the levels of arsenic were lower than $1 \mu \mathrm{g} / \mathrm{L}$ in those three cities.) These 129 wells represent approximately $81 \%$ of the total number of wells that are supplying water to those 17 communities.

The water samples were collected in prewashed polyethylene bottles from public water wells under normal oper- ating conditions, that is, delivering water to the public water system. Samples were taken manually from the wellhead sampling port of each well. Before the sampling, a bottle was rinsed three times with water from the same well. In order to get a representative sample (free of any contamination from the pipe line), the sampling port was first purged for several minutes. Water samples were preserved by adding trace-grade nitric acid. The samples were then stored at approximately $5{ }^{\circ} \mathrm{C}$.

Two series of water samples were taken. The first series was collected during November 2002, and the second in October 2003. Three water samples per well were taken during each series.

\section{Analytical}

The total arsenic concentration in the water samples was determined by inductively coupled plasma-optical emission spectroscopy (ICP-OES). The instrument used was an Optima 4300 DV ICP-OES (PerkinElmer, Shelton, Connecticut, United States). The correlation coefficients for the wavelengths used (188.979 and $197.197 \mathrm{~nm}$ ) were in the range of 0.9970 to 0.9999 .

Temperature, $\mathrm{pH}$, and conductivity were determined by using selective electrodes.

\section{Data analysis}

Statistical analysis was performed to obtain the arithmetical mean and standard deviation for each of the physical and chemical properties measured in this study. A standard spreadsheet was used to calculate those statistical values. The distribution of arsenic in the groundwaters of the study area was presented graphically by using a geographic information system. The average concentrations of arsenic for each of the municipal capitals were assigned to polygon coverage of the municipality boundaries. In addition, a pie graph has been used to show the percentage distribution of the water wells according to the level of arsenic. 


\section{Exposure levels}

The daily exposure doses to arsenic in drinking water were estimated by using this equation:

$$
\mathrm{ED}=\mathrm{I}_{\text {Water }} / \mathrm{W}_{\text {Body }}
$$

where

$\begin{aligned} \mathrm{ED}= & \text { daily exposure dose to arsenic } \\ & \text { in drinking water, in } \mu \mathrm{g} / \mathrm{d} / \mathrm{kg} \\ \mathrm{I}_{\text {Water }}= & \text { daily intake of arsenic from } \\ & \text { drinking water, in } \mu \mathrm{g} / \mathrm{d} \\ \mathrm{W}_{\text {Body }}= & \text { individual body weight, in } \mathrm{kg}\end{aligned}$

Daily intake of arsenic from drinking water was calculated by using the next equation:

$$
\mathrm{I}_{\text {Water }}=\mathrm{C}_{\text {Water }} \mathrm{IR}_{\text {Water }}
$$

where

$$
\begin{aligned}
\mathrm{C}_{\text {Water }}= & \text { total arsenic concentration in } \\
& \text { drinking water, in } \mu \mathrm{g} / \mathrm{L} \\
\mathrm{IR}_{\text {Water }}= & \text { water intake rate via inges- } \\
& \text { tion, in } \mathrm{L} / \mathrm{d}
\end{aligned}
$$

A simulation process was developed to estimate the levels of exposure to arsenic (daily intake of arsenic and daily exposure doses to arsenic) for persons living in the LAJ region. In this study, three groups of people were arbitrary selected: babies (12 months old and weighing $10 \mathrm{~kg}$ ), children (6 years old and weighing $20 \mathrm{~kg}$ ), and adults ( 25 years old and weighing $70 \mathrm{~kg}$ ). Calculations were based on the following assumptions: (1) the babies' daily diet included a food formula prepared with $750 \mathrm{~mL}$ of tap water, (2) the children's daily diet included $1000 \mathrm{~mL}$ of tap water, and (3) the adults' daily diet included $1850 \mathrm{~mL}$ of tap water. (A previous publication (22) had suggested using these values to estimate the levels of exposure to fluoride in the LAJ region.) We estimated the mean, minimum, and maximum daily exposure doses to arsenic by using, respectively, the mean, minimum, and maximum concentrations of total arsenic in drinking water that we had found from our sampling of the wells.

\section{RESULTS}

The information on arsenic levels, temperature, $\mathrm{pH}$, and electric conduc- tivity (EC) for the wells in each of the 17 municipal capitals is given in Table 1. In addition, a visual presentation of the arithmetic mean, minimum value, and maximum value of the arsenic levels of the wells in each of the 17 municipal capitals is given in Figure 3.

The mean total arsenic concentrations in the 17 LAJ municipal capitals ranged from $14.7 \mu \mathrm{g} / \mathrm{L}$ (city of Arandas) to $101.9 \mu \mathrm{g} / \mathrm{L}$ (city of Mexticacán). While all of the 17 municipal capitals had a mean concentration of total arsenic higher than $10 \mu \mathrm{g} / \mathrm{L}$ (the guideline value set by the $\mathrm{WHO}$ ), only 7 of them exceeded the Mexican national guideline value for arsenic of $25 \mu \mathrm{g} / \mathrm{L}$. These cities were Encarnación de Díaz, Mexticacán, Ojuelos de Jalisco, San Juan de los Lagos, San Miguel el Alto, Teocaltiche, and Valle de Guadalupe. With the exception of San Miguel el Alto, the other 6 cities had a mean well-water temperature higher than $30{ }^{\circ} \mathrm{C}$, indicating origin or contamination from deeper geothermal waters. Even though the mean temperature of

\begin{tabular}{|c|c|c|c|c|c|c|c|c|c|c|c|c|c|c|}
\hline \multirow[b]{2}{*}{ Municipal capital } & \multirow[b]{2}{*}{ Population ${ }^{a}$} & \multirow{2}{*}{$\begin{array}{l}\text { No. of } \\
\text { wells }\end{array}$} & \multicolumn{3}{|c|}{ Temperature $\left({ }^{\circ} \mathrm{C}\right)$} & \multicolumn{3}{|c|}{$\mathrm{pH}$} & \multicolumn{3}{|c|}{$\mathrm{EC}(\mu \mathrm{S} / \mathrm{cm})$} & \multicolumn{3}{|c|}{ Arsenic $(\mu \mathrm{g} / \mathrm{L})$} \\
\hline & & & Mean & $\operatorname{Min}^{b}$ & $\operatorname{Max}^{\mathrm{c}}$ & Mean & Min & Max & Mean & Min & $\operatorname{Max}$ & Mean & Min & Max \\
\hline Acatic & 11005 & 4 & 32.4 & 31.2 & 33.7 & 6.7 & 6.5 & 7.0 & 252 & 182 & 297 & 16.5 & 5.1 & 30.8 \\
\hline Arandas & 39478 & 11 & 28.0 & 23.3 & 32.8 & 6.5 & 6.2 & 6.7 & 279 & 230 & 408 & 14.7 & 3.8 & 26.1 \\
\hline Encarnación de Díaz & 20772 & 6 & 30.1 & 25.8 & 36.6 & 7.1 & 7.0 & 7.4 & 537 & 451 & 661 & 25.2 & 17.9 & 42.8 \\
\hline Jalostotitlán & 21291 & 5 & 26.8 & 24.7 & 29.3 & 7.0 & 6.8 & 7.0 & 459 & 417 & 494 & 23.4 & 18.1 & 29.8 \\
\hline Jess María & 7852 & 4 & 27.3 & 24.1 & 31.3 & 6.5 & 6.5 & 6.7 & 413 & 206 & 421 & 22.8 & 4.0 & 52.6 \\
\hline Lagos de Moreno & 79592 & 18 & 30.2 & 22.2 & 35.2 & 7.0 & 6.5 & 7.5 & 556 & 395 & 1084 & 21.8 & 10.8 & 43.3 \\
\hline Mexticacán & 3603 & 4 & 30.3 & 26.6 & 37.7 & 7.2 & 7.1 & 7.3 & 563 & 489 & 691 & 101.9 & 12.9 & 262.9 \\
\hline Ojuelos de Jalisco & 9338 & 3 & 37.5 & 36.4 & 38.7 & 6.9 & 6.9 & 7.0 & 548 & 548 & 548 & 28.3 & 20.5 & 33.9 \\
\hline San Diego de Alejandría & 4749 & 2 & 27.5 & 27.4 & 27.7 & 7.4 & 7.3 & 7.5 & 475 & 434 & 517 & 20.7 & 4.8 & 52.2 \\
\hline San Juan de los Lagos & 42411 & 11 & 32.2 & 26.7 & 45.2 & 7.1 & 6.9 & 7.5 & 830 & 474 & 1888 & 54.5 & 0.5 & 113.8 \\
\hline San Julián & 12117 & 3 & 26.2 & 25.1 & 27.3 & 7.0 & 6.8 & 7.1 & 452 & 439 & 467 & 20.3 & 8.6 & 62.0 \\
\hline San Miguel el Alto & 21098 & 6 & 25.7 & 22.6 & 28.7 & 7.2 & 7.0 & 7.3 & 553 & 347 & 922 & 30.8 & 5.8 & 74.8 \\
\hline Teocaltiche & 21518 & 5 & 30.6 & 26.2 & 33.9 & 6.8 & 6.6 & 7.2 & 796 & 620 & 1074 & 89.5 & 54.0 & 157.7 \\
\hline Tepatitlán de Morelos & 74262 & 27 & 30.9 & 24.0 & 42.3 & 6.7 & 5.9 & 8.0 & 310 & 177 & 576 & 22.1 & 4.5 & 74.0 \\
\hline Unión de San Antonio & 6317 & 3 & 26.8 & 24.6 & 30.2 & 7.2 & 7.0 & 7.4 & 429 & 427 & 431 & 20.0 & 6.1 & 31.8 \\
\hline Valle de Guadalupe & 4178 & 4 & 35.0 & 33.9 & 36.8 & 7.0 & 6.8 & 7.3 & 479 & 375 & 548 & 28.2 & 16.5 & 47.0 \\
\hline Villa Hidalgo & 11552 & 13 & 28.5 & 25.7 & 32.4 & 6.3 & 6.0 & 7.2 & 171 & 155 & 204 & 16.3 & 4.0 & 36.5 \\
\hline Total/Overall & 391133 & 129 & 29.9 & 22.2 & 45.2 & 6.8 & 5.9 & 8.0 & 447.1 & 155 & 1888 & 29.4 & 0.5 & 262.9 \\
\hline
\end{tabular}
the wells in the cities of Acatic, Lagos de Moreno, and Tepatitlán de Morelos was greater than $30^{\circ} \mathrm{C}$, the mean ar-

TABLE 1. Data on water wells, including temperature, $\mathrm{pH}$, electric conductivity (EC), and total arsenic concentration, in municipal capitals in the Los Altos de Jalisco region of Mexico, 2002-2003

a The population data for the municipal capitals are from the Instituto Nacional de Estadística, Geografía e Informática (1).

${ }^{\mathrm{b}}$ Min $=$ minimum.

${ }^{\mathrm{c}} \mathrm{Max}=$ maximum . 
FIGURE 3. Arsenic levels, with minimum, mean, and maximum, in water wells in the municipal capitals of the Los Altos de Jalisco region of Mexico, 2002-2003

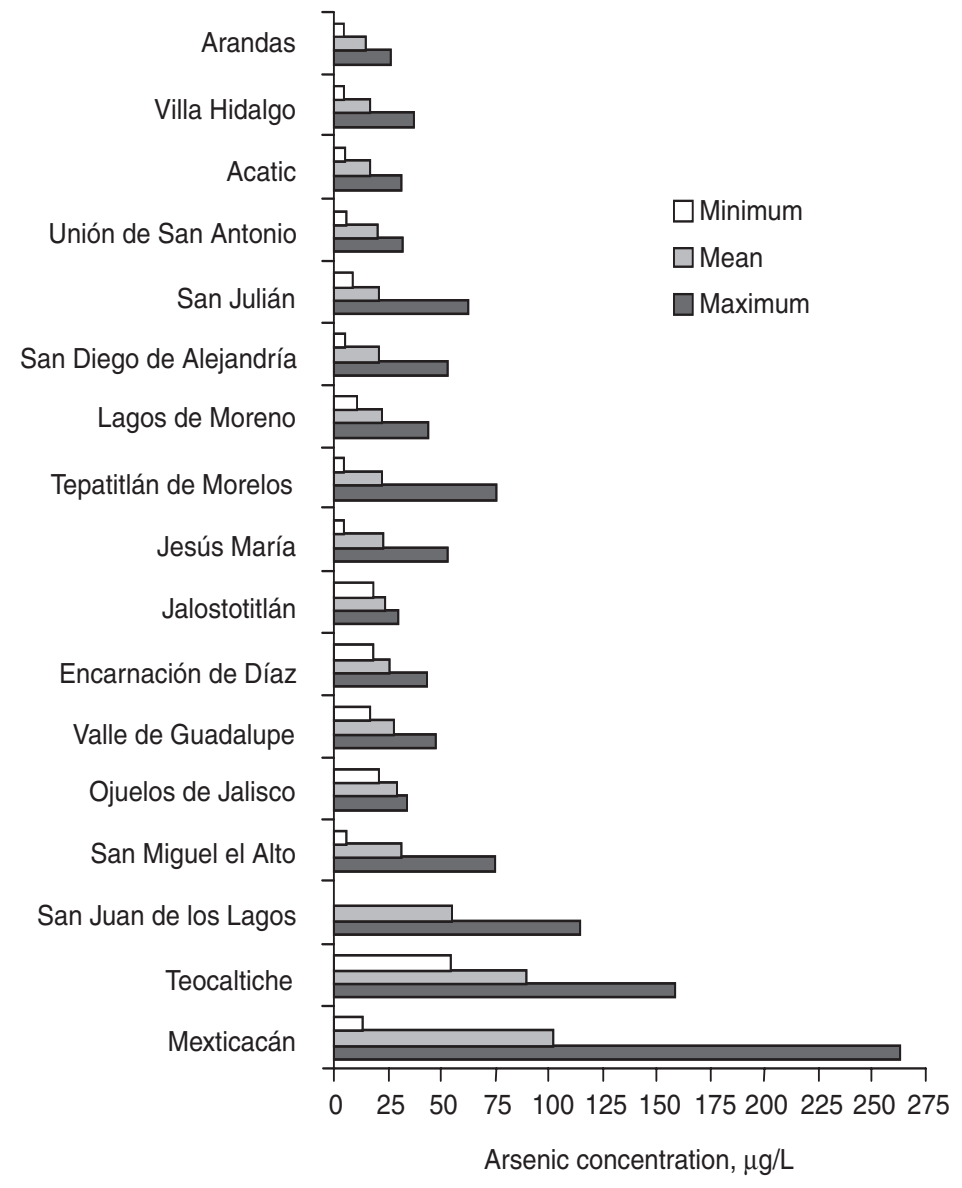

a The municipal capitals are ordered by the mean arsenic concentration.

senic concentrations for each of those three cities was lower than $25 \mu \mathrm{g} / \mathrm{L}$. The total population of the 7 cities that had wells exceeding the Mexican national guideline value for arsenic was around 125000 persons.

The cities with the highest mean concentrations of total arsenic were Mexticacán $(101.9 \mu \mathrm{g} / \mathrm{L})$, Teocaltiche $(89.5 \mu \mathrm{g} / \mathrm{L})$, and San Juan de los Lagos $(54.5 \mu \mathrm{g} / \mathrm{L})$. These data suggest that the approximately 70000 inhabitants in these three cities could be under serious health risk due to the chronic ingestion of high levels of arsenic from drinking water. Assuming that the WHO guideline value for arsenic of 10 $\mu \mathrm{g} / \mathrm{L}$ is a better criterion for protecting human health, more than 400000 resi- dents of the LAJ region could be facing some potential health risks.

Of the 129 wells sampled in the 17 municipal capitals, 44 of the wells, in 13 municipal capitals, had a mean total arsenic concentration exceeding 25 $\mu \mathrm{g} / \mathrm{L}$ (Table 2). Of these 44 wells, the water from 23 of them, located in 13 municipal capitals, had a mean temperature higher than $30^{\circ} \mathrm{C}$.

Electric conductivity is an indirect measure of total dissolved solid concentration. Due to technical problems, EC was not accurately measured in 17 wells. In the 112 water wells accurately tested, the EC ranged from 155 to 1888 $\mu \mathrm{S} / \mathrm{cm}$. The highest value was measured in Well No. 1 in San Juan de los Lagos. Other wells with very high EC values were found in Lagos de Moreno (Well O, $1084 \mu \mathrm{S} / \mathrm{cm}$ ) and in Teocaltiche (Well No. 5, $1074 \mu \mathrm{S} / \mathrm{cm}$ ). In general, there was a positive correlation between arsenic concentration and conductivity. The $\mathrm{pH}$ of the water wells tested ranged from 5.9 to 8.0.

Table 3 shows the number of water wells tested in each of the municipal capitals and the number and percentage of the wells in each capital that met the international WHO guideline value for arsenic $(10 \mu \mathrm{g} / \mathrm{L})$ and the Mexican national guideline value (25 $\mu \mathrm{g} / \mathrm{L})$. While 85 of the 129 water wells sampled $(66 \%)$ met the Mexican national guideline value, only 10 wells (8\%) met the WHO guideline value. The data from Table 3 also show that: (a) there were 3 cities where $100 \%$ of the sampled wells had a total mean arsenic concentration greater than 25 $\mu \mathrm{g} / \mathrm{L},(\mathrm{b})$ there were 13 cities where at least one well had a total arsenic concentration greater than $25 \mu \mathrm{g} / \mathrm{L}$, and (c) there were 4 cities where $100 \%$ of the sampled water wells met the national guideline value. Graphic depictions of the distributions of the values for the arsenic concentration for the 129 wells are given in Figure 4, Figure 5, and Figure 6.

Figure 7 shows the distribution of the mean arsenic concentrations in the groundwaters in the LAJ region. The range into which the mean concentration of arsenic in each of the municipal capitals falls is represented by the intensity of the shading. The three white areas correspond to the municipal capitals of Cañadas de Obregón, Cuquío, and Yahualica de González Gallo, which each had a mean total arsenic concentration in the range of 0 to 1 $\mu \mathrm{g} / \mathrm{L}$ (as noted earlier in this article, these three municipal capitals are being supplied with surface water).

The estimated daily exposure doses to arsenic in drinking water in the 17 municipal capitals are presented in Table 4. Mexticacán, Teocaltiche, and San Juan de los Lagos were the cities with the highest estimated levels of exposure. The range of values estimated for the arsenic exposure doses were: babies, $1.1-7.6 \mu \mathrm{g} / \mathrm{kg} / \mathrm{d}$; children, $0.7-5.1$ $\mu \mathrm{g} / \mathrm{kg} / \mathrm{d}$; and adults, $0.4-2.7 \mu \mathrm{g} / \mathrm{kg} / \mathrm{d}$. 
TABLE 2. Total arsenic concentration and other physical properties of well waters that exceed the Mexican national guideline value of $25 \mu \mathrm{g} / \mathrm{L}$ for arsenic, in the Los Altos de Jalisco region of Mexico, 2002-2003

\begin{tabular}{|c|c|c|c|c|c|c|}
\hline \multirow[b]{2}{*}{ Municipal capital/Well } & \multirow{2}{*}{$\begin{array}{c}\text { Temperature } \\
\left({ }^{\circ} \mathrm{C}\right)\end{array}$} & \multirow[b]{2}{*}{$\mathrm{pH}$} & \multirow{2}{*}{$\begin{array}{c}E C^{\mathrm{a}} \\
(\mu \mathrm{S} / \mathrm{cm})\end{array}$} & \multicolumn{3}{|c|}{ Arsenic $(\mu \mathrm{g} / \mathrm{L})$} \\
\hline & & & & Mean & $\operatorname{Min}^{b}$ & $\operatorname{Max}^{\mathrm{C}}$ \\
\hline \multicolumn{7}{|l|}{ Encarnación de Díaz } \\
\hline Well No. 1 & 26.8 & 7.0 & 451 & 25.7 & 23.7 & 28.6 \\
\hline Well No. 2 & 27.0 & 7.4 & $\ldots{ }^{d}$ & 28.8 & 26.7 & 30.8 \\
\hline Well No. 6 & 25.8 & 7.2 & 661 & 30.9 & 23.2 & 42.8 \\
\hline \multicolumn{7}{|l|}{ Jalostotitlán } \\
\hline Well No. 1 & 24.7 & 7.0 & 494 & 27.4 & 25.0 & 29.8 \\
\hline Well No. 4 & 25.7 & 7.0 & 446 & 26.0 & 24.2 & 27.9 \\
\hline \multicolumn{7}{|l|}{ Jesús María } \\
\hline Well No. 4 & 24.1 & 6.5 & $\ldots$ & 28.1 & 10.4 & 52.5 \\
\hline \multicolumn{7}{|l|}{ Lagos de Moreno } \\
\hline Well J & 35.2 & 6.5 & 395 & 25.2 & 23.6 & 27.8 \\
\hline Well O & 23.8 & 7.3 & 1084 & 28.1 & 13.8 & 39.4 \\
\hline Well Q & 22.2 & 7.2 & 830 & 29.6 & 20.8 & 43.3 \\
\hline \multicolumn{7}{|l|}{ Mexticacán } \\
\hline Well No. 1 & 26.9 & 7.1 & 565 & 45.1 & 36.5 & 63.1 \\
\hline Well No. 2 & 30.0 & 7.3 & 489 & 62.3 & 51.5 & 68.1 \\
\hline Well No. 3 & 37.7 & 7.1 & 691 & 222.6 & 197.0 & 262.9 \\
\hline \multicolumn{7}{|l|}{ Ojuelos de Jalisco } \\
\hline Well A & 37.4 & 6.9 & & 29.8 & 24.9 & 31.9 \\
\hline Well B & 36.3 & 6.9 & 548 & 28.8 & 24.8 & 33.9 \\
\hline Well C & 38.7 & 7.0 & $\ldots$ & 26.4 & 20.5 & 31.6 \\
\hline \multicolumn{7}{|l|}{ San Juan de los Lagos } \\
\hline Well No. 1 & 42.6 & 7.0 & 1888 & 100.3 & 88.7 & 113.8 \\
\hline Well No. 2 & 31.1 & 7.5 & 1045 & 67.8 & 55.4 & 87.8 \\
\hline Well No. 3 & 29.5 & 7.3 & 491 & 29.2 & 8.7 & 52.2 \\
\hline Well No. 4 & 45.2 & 7.1 & & 73.7 & 73.7 & 73.7 \\
\hline Well No. 7 & 34.6 & 7.1 & 488 & 40.6 & 32.0 & 47.1 \\
\hline Well No. 11 & 29.6 & 7.0 & 531 & 38.0 & 16.2 & 76.5 \\
\hline Well No. 13 & 29.0 & 6.9 & 762 & 34.8 & 0.5 & 58.6 \\
\hline Well No. 15 & 27.0 & 7.0 & 672 & 67.9 & 56.4 & 73.0 \\
\hline Well No. 17 & 29.3 & 7.2 & & 74.2 & 69.5 & 78.9 \\
\hline Well No. 18 & 32.1 & 7.0 & 1125 & 87.3 & 79.2 & 96.6 \\
\hline \multicolumn{7}{|l|}{ San Julián } \\
\hline Well No. 1 & 25.1 & 6.8 & 439 & 27.8 & 11.6 & 62.0 \\
\hline \multicolumn{7}{|l|}{ San Miguel el Alto } \\
\hline Well No. 2 & 22.6 & 7.2 & 922 & 59.1 & 43.4 & 74.8 \\
\hline Well No. 5 & 24.1 & 7.2 & $\ldots$ & 48.0 & 48.0 & 48.0 \\
\hline \multicolumn{7}{|l|}{ Teocaltiche } \\
\hline Well No. 2 & 31.9 & 6.8 & 772 & 75.0 & 60.9 & 82.4 \\
\hline Well No. 3 & 28.2 & 6.6 & 647 & 73.3 & 56.3 & 88.7 \\
\hline Well No. 4 & 34.8 & 6.7 & 620 & 142.8 & 129.0 & 157.7 \\
\hline Well No. 5 & 31.8 & 6.6 & 1074 & 95.5 & 77.2 & 114.4 \\
\hline Well No. 6 & 26.2 & 7.2 & 866 & 71.2 & 54.0 & 105.0 \\
\hline \multicolumn{7}{|l|}{ Tepatitlán de Morelos } \\
\hline Well No. 9 & 37.9 & 6.5 & 342 & 33.8 & 26.3 & 38.7 \\
\hline Well No. 10 & 42.3 & 6.9 & 576 & 69.5 & 61.3 & 75.0 \\
\hline Well No. 17 & 37.9 & 6.8 & 422 & 44.2 & 41.6 & 47.5 \\
\hline Well No. 20 & 32.5 & 6.8 & 423 & 47.4 & 44.8 & 48.9 \\
\hline Well No. 21 & 41.9 & 6.8 & 313 & 27.3 & 25.2 & 30.4 \\
\hline Well No. 22 & 24.0 & 6.0 & 450 & 25.5 & 23.3 & 27.8 \\
\hline Valle de Guadalupe & & & & & & \\
\hline Well No. 1 & 34.8 & 7.0 & 548 & 28.7 & 22.4 & 47.0 \\
\hline Well No. 2 & 33.9 & 7.1 & 508 & 32.9 & 24.1 & 44.1 \\
\hline Well No. 3 & 36.8 & 6.8 & 375 & 25.6 & 19.8 & 32.3 \\
\hline Well No. 4 & 34.7 & 7.3 & 484 & 25.4 & 16.5 & 32.6 \\
\hline Villa Hidalgo & & & & & & \\
\hline Well No. 17 & 25.7 & 6.5 & 204 & 33.4 & 30.2 & 36.5 \\
\hline
\end{tabular}

${ }^{\mathrm{a}} \mathrm{EC}=$ electric conductivity.

${ }^{\mathrm{b}}$ Min $=$ minimum.

${ }^{c}$ Max $=$ maximum.

${ }^{\mathrm{d}}$ The ellipsis points (.. . ) indicate missing data, where, due to technical problems, EC was not accurately measured.

\section{DISCUSSION}

\section{Arsenic occurrence}

Three main factors are essential to the presence of arsenic in groundwater: (1) a source of arsenic (minerals, rocks, sediments, and soils), (2) environmental conditions to enhance mobilization of arsenic (temperature, $\mathrm{pH}$, redox potential, and chemical species), and (3) physical and chemical phenomena that increase the transport processes (adsorption-desorption) $(8,23)$.

In natural waters, arsenic can occur in several oxidation states $(-3,0,+3$, and +5$)$, but it is present mainly as arsenite $(\mathrm{As}(\mathrm{III}))$ and arsenate $(\mathrm{As}(\mathrm{V}))$ oxyanions. While speciation of arsenic is strongly dependent on both redox potential and $\mathrm{pH}(8)$, other important factors, such as temperature and the occurrence of metallic sulfide and oxides, also affect arsenic speciation. Under reducing conditions, such as those often found in underground aquifers, arsenite is generally the most common species present (24). The level of dissolved arsenic in natural waters is predominantly controlled by the capacity of some metallic oxides present in aquifers to absorb or desorb arsenites and arsenates (25). From the health point of view, the oxidation state of arsenic is important. Trivalent arsenic (As(III)) is more toxic than pentavalent arsenic $(\mathrm{As}(\mathrm{V}))$ is.

Our study has shown that the total arsenic concentrations in the LAJ groundwater fall on the lower boundary of both subsurface natural waters $(<0.5$ to $5000 \mu \mathrm{g} / \mathrm{L})(8)$ and of deep geothermal waters $(<100$ to $50000 \mu \mathrm{g} / \mathrm{L})$ (26). The data that we collected do not make it possible to establish the oxidation states of arsenic in the LAJ groundwaters. Nevertheless, the mean $\mathrm{pH}$ values (from 6.3 to 7.4 ), depth of the water wells (ranging from approximately $50 \mathrm{~m}$ to $550 \mathrm{~m}$ ), and high proportion of volcanic rocks in the aquifers indicate that reducing conditions might exist in the LAJ groundwater supplies $(25,27$, 28). The data in Table 1 suggest that there are two groups of aquifers in the LAJ region. One group shows a positive correlation between arsenic and 
TABLE 3. Number and percentage of water wells in the municipal capitals of the Los Altos de Jalisco region of Mexico, by range of the mean total arsenic concentration, 2002-2003

\begin{tabular}{|c|c|c|c|c|c|c|c|}
\hline \multirow[b]{3}{*}{ Municipal capital } & \multirow{3}{*}{$\begin{array}{l}\text { Total } \\
\text { no. of } \\
\text { wells }\end{array}$} & \multicolumn{6}{|c|}{ Concentration of arsenic $(\mu \mathrm{g} / \mathrm{L})$} \\
\hline & & \multicolumn{2}{|c|}{$0<C_{W} \leq 10^{a}$} & \multicolumn{2}{|c|}{$10<C_{W} \leq 25$} & \multicolumn{2}{|c|}{$C_{W}>25$} \\
\hline & & No. & $\%$ & No. & $\%$ & No. & $\%$ \\
\hline Acatic & 4 & 1 & 25 & 3 & 75 & 0 & 0 \\
\hline Arandas & 11 & 2 & 18 & 9 & 82 & 0 & 0 \\
\hline Encarnación de Díaz & 6 & 0 & 0 & 3 & 50 & 3 & 50 \\
\hline Jalostotitlán & 5 & 0 & 0 & 3 & 60 & 2 & 40 \\
\hline Jesús María & 4 & 0 & 0 & 3 & 75 & 1 & 25 \\
\hline Lagos de Moreno & 18 & 0 & 0 & 15 & 83 & 3 & 17 \\
\hline Mexticacán & 4 & 0 & 0 & 1 & 25 & 3 & 75 \\
\hline Ojuelos de Jalisco & 3 & 0 & 0 & 0 & 0 & 3 & 100 \\
\hline San Diego de Alejandría & 2 & 0 & 0 & 2 & 100 & 0 & 0 \\
\hline San Juan de los Lagos & 11 & 0 & 0 & 1 & 9 & 10 & 91 \\
\hline San Julián & 3 & 0 & 0 & 2 & 67 & 1 & 33 \\
\hline San Miguel el Alto & 6 & 0 & 0 & 4 & 67 & 2 & 33 \\
\hline Teocaltiche & 5 & 0 & 0 & 0 & 0 & 5 & 100 \\
\hline Tepatitlán de Morelos & 27 & 4 & 15 & 17 & 63 & 6 & 22 \\
\hline Unión de San Antonio & 3 & 1 & 33 & 2 & 67 & 0 & 0 \\
\hline Valle de Guadalupe & 4 & 0 & 0 & 0 & 0 & 4 & 100 \\
\hline Villa Hidalgo & 13 & 2 & 15 & 10 & 77 & 1 & 8 \\
\hline Total/Overall & 129 & 10 & 8 & 75 & 58 & 44 & 34 \\
\hline
\end{tabular}

${ }^{\mathrm{a}} \mathrm{C}_{\mathrm{W}}=$ concentration of arsenic in the well water.

FIGURE 4. Distribution of arsenic concentrations $\left(C_{w}\right)$ in water wells in the municipal capitals of the Los Altos de Jalisco region of Mexico, 2002-2003

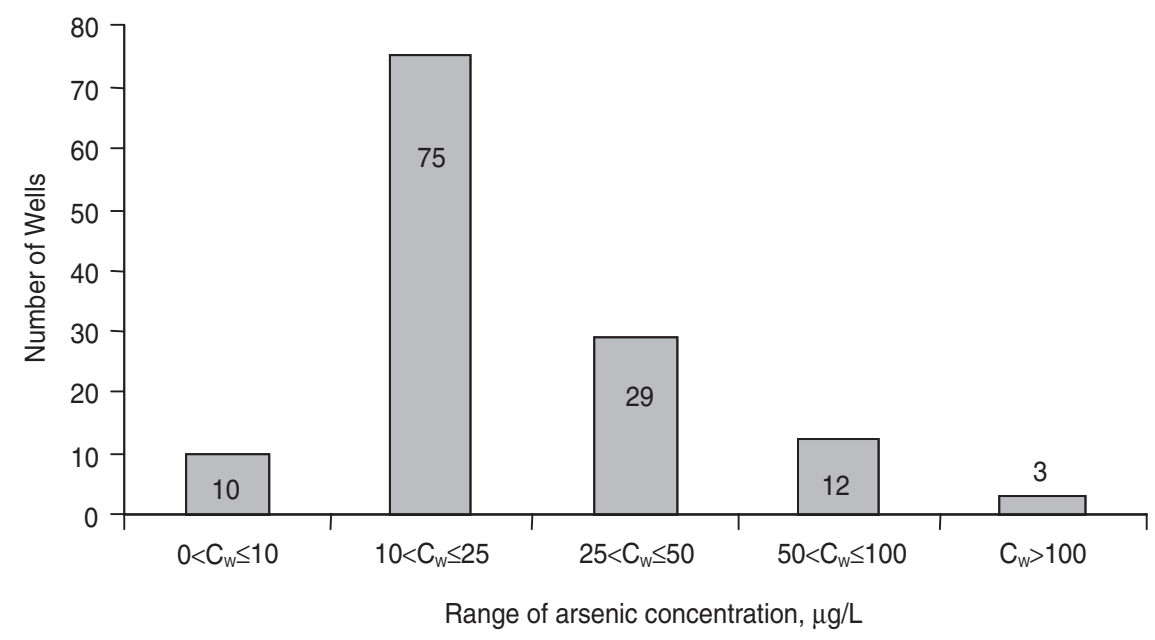

temperature. Another group shows a negative correlation. In general, highertemperature aquifers have shown a positive correlation. Correlations between $\mathrm{pH}$ and arsenic concentration have also shown both positive and negative patterns.
FIGURE 5. Percentage of water wells in the municipal capitals of the Los Altos de Jalisco region of Mexico, by range of arsenic concentration $\left(C_{w}\right)(\mu \mathrm{g} / L), 2002-2003$

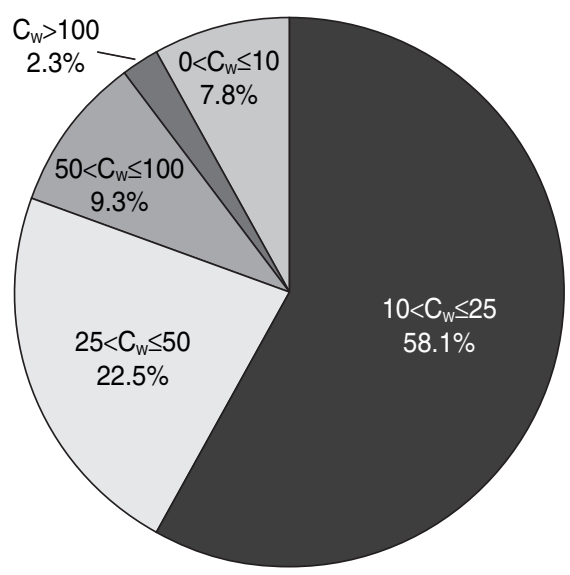

are consuming contaminated water. This situation might represent a serious human health risk for the inhabitants of this area and for any people who consume agricultural or livestock products that come from this region.

In the LAJ region, both agricultural and livestock activities are very intensive and highly groundwaterdependent, with more than 1600 water wells in use (29). Only $10 \%$ of these wells are being used to supply potable water (for drinking, cooking, and other household purposes). The use of contaminated water represents a serious environmental problem for the regional ecosystem, mainly for human beings, and the situation needs to be dealt with as soon as possible. Transportation of arsenic from groundwater to the environment via the food chain could be seriously affecting the health of the residents of the LAJ region.

Some vegetables, such as corn and potatoes, can accumulate very high levels of arsenic. The amount of arsenic accumulated by food crops is a direct function of the arsenic concentration in the irrigation water (30). In Socaire, a small town located in a volcanic area in northern Chile, where water for agri- 
FIGURE 6. Cumulative distribution of arsenic concentrations in water wells in the municipal capitals of the Los Altos de Jalisco region of Mexico, 2002-2003

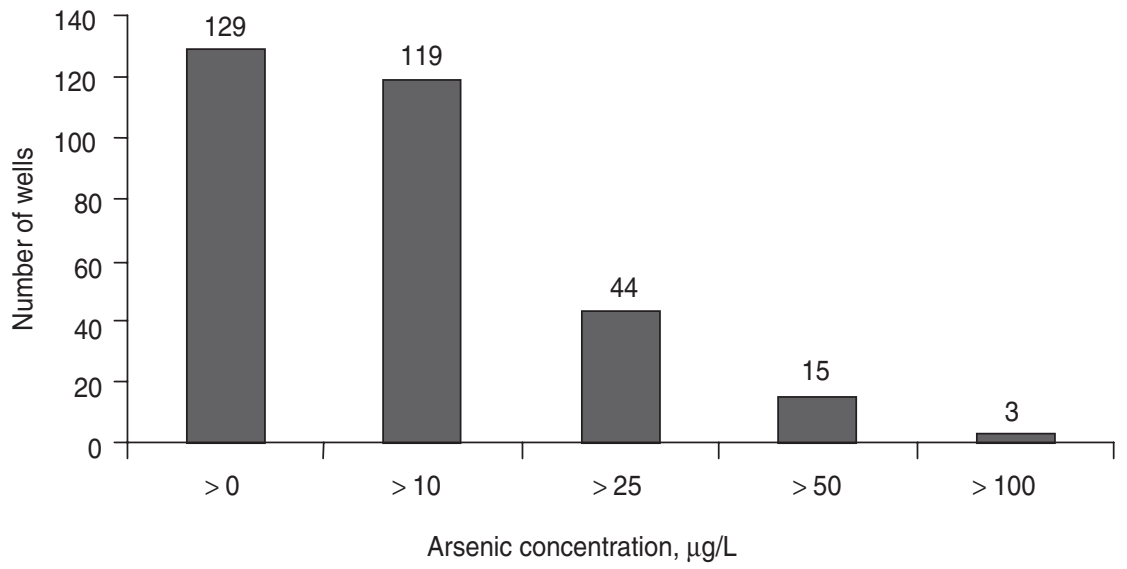

FIGURE 7. Distribution of the mean arsenic concentration in the groundwaters of the municipalities in the Los Altos de Jalisco region of Mexico, 2002-2003a
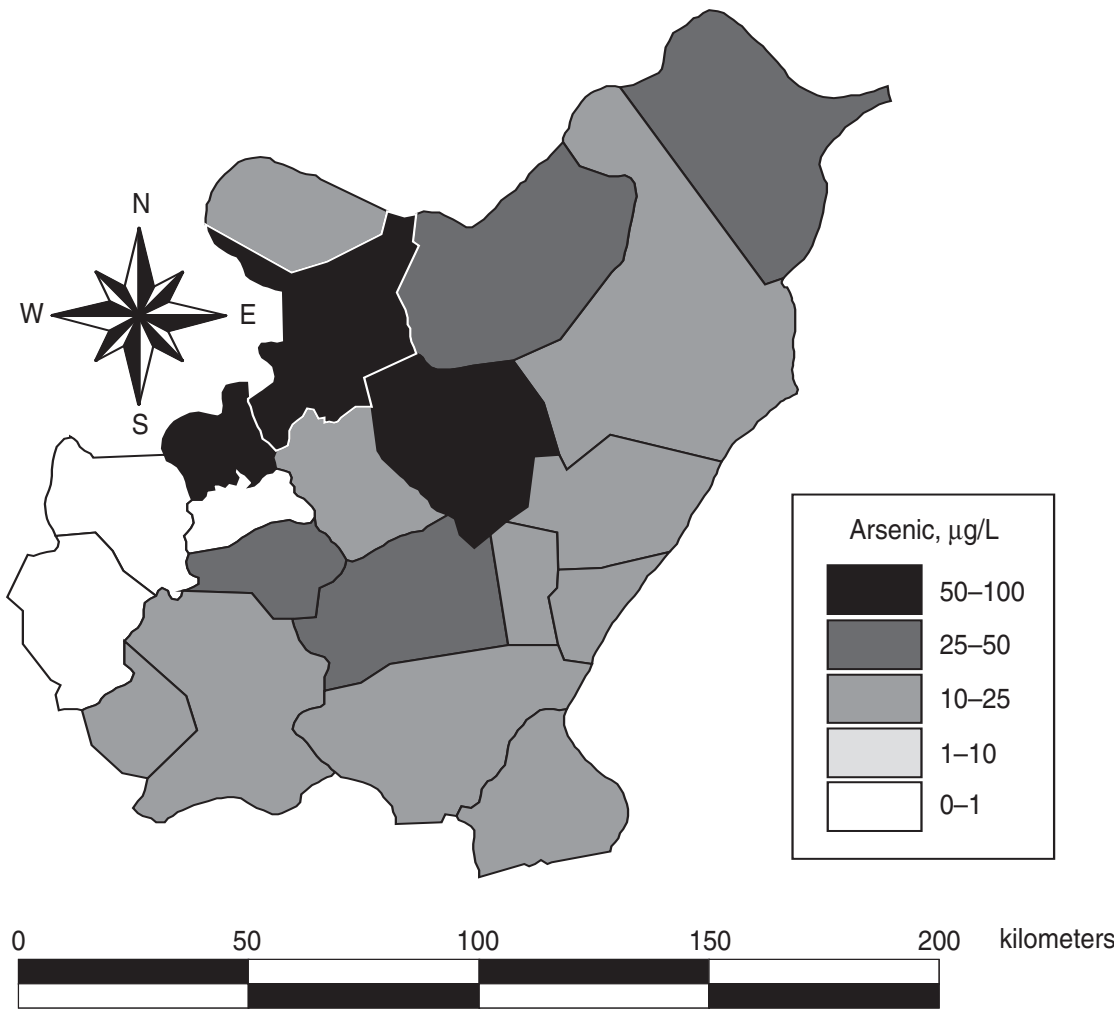

a The arsenic concentration in the potable water of Cañadas de Obregón, Cuquío, and Yahualica de González Gallo (the three areas shown in white) was not analyzed in this study because their water supply comes only from surface water. A preliminary study performed by the authors of this study (not published) found that the arsenic concentrations in those cities were lower than $1 \mu \mathrm{g} / \mathrm{L}$.

culture has 150-250 $\mathrm{\mu g}$ As/L (31), high levels of arsenic were found in corn $(1848 \mu \mathrm{g} / \mathrm{kg})$ and potatoes $(864 \mu \mathrm{g} / \mathrm{kg})$. While agricultural products grown in the LAJ fields are being irrigated with arsenic-contaminated waters, there is no information on the arsenic levels in these products.

\section{Human exposure to arsenic}

Arsenic in the LAJ region is ingested via three main routes: drinking water, eating food, and consuming hot beverages (tea and/or coffee). In this study we have used two sets of data: (1) the concentration of arsenic in the water samples that we studied and (2) the levels of arsenic in foods, obtained from the scientific literature. The intake of arsenic from hot beverages and food in countries such as Bangladesh, Canada, Chile, Croatia, India, Japan, Mexico, Spain, and the United States has been well documented $(17,30-38)$, but there is no information about that for the LAJ region. Nevertheless, data on the daily intake of total arsenic in food from other regions similar to the $\operatorname{LAJ}(17,35$, 38,39 ) have been used in the simulation process to estimate exposure doses in a more accurate manner.

The studies for other countries mentioned in the preceding paragraph indicate that the highest levels of arsenic are found in seafood, cereals, meat, and meat by-products. Approximately $90 \%$ of the dietary intake of total arsenic comes from seafood. Most seafood arsenic (80\%-99\%) is present in organic forms, which are less toxic (32). Estimates of the mean daily intake of total arsenic in food for adults range from 42 $\mu \mathrm{g}$ in Canada to $286 \mu \mathrm{g}$ in Spain (40).

The Joint Food and Agriculture Organization/World Health Organization Expert Committee on Food Additives has evaluated arsenic toxicity, and has established a provisional tolerable weekly intake (PTWI) of $15 \mu \mathrm{g} /$ $\mathrm{kg} / \mathrm{w}$ for inorganic arsenic, equivalent to a provisional tolerable daily intake (PTDI) of $2.14 \mu \mathrm{g} / \mathrm{kg} / \mathrm{d}$. (PTWI is an estimate of the amount of a contaminant that can be ingested weekly over a lifetime without appreciable health risk (41).) Daily exposure doses greater than the PTDI might represent a potential health risk. Using the recommended PTDI values of the Expert Committee, the provisional tolerable daily intake of arsenic for babies $(10 \mathrm{~kg})$, children $(20 \mathrm{~kg})$, and adults $(70 \mathrm{~kg}$ ) living in LAJ region is 21.4, 42.8, and $150.0 \mu \mathrm{g} \mathrm{As} / \mathrm{d}$, respectively. These values indicate that the maxi- 
TABLE 4. Estimated daily exposure dose $(\mu \mathrm{g} / \mathrm{kg} / \mathrm{d})$ of arsenic in drinking water, with mean, minimum $(\mathrm{min})$ value, and maximum (max) value, for babies, children, and adults in the municipal capitals of the Los Altos de Jalisco region of Mexico, 2002-2003a

\begin{tabular}{|c|c|c|c|c|c|c|c|c|c|}
\hline \multirow[b]{2}{*}{ Municipal capital } & \multicolumn{3}{|c|}{ Babies $(10 \mathrm{~kg})$} & \multicolumn{3}{|c|}{ Children $(20 \mathrm{~kg})$} & \multicolumn{3}{|c|}{ Adults $(70 \mathrm{~kg})$} \\
\hline & Mean & Min & Max & Mean & Min & Max & Mean & Min & Max \\
\hline Acatic & 1.2 & 0.4 & 2.3 & 0.8 & 0.3 & 1.5 & 0.4 & 0.1 & 0.8 \\
\hline Encarnación de Díaz & 1.9 & 1.3 & 3.2 & 1.3 & 0.9 & 2.1 & 0.7 & 0.5 & 1.1 \\
\hline Jalostotitlán & 1.8 & 1.4 & 2.2 & 1.2 & 0.9 & 1.5 & 0.6 & 0.5 & 0.8 \\
\hline Jesús María & 1.7 & 0.3 & 3.9 & 1.1 & 0.2 & 2.6 & 0.6 & 0.1 & 1.4 \\
\hline San Diego de Alejandría & 1.6 & 0.4 & 3.9 & 1.0 & 0.2 & 2.6 & 0.5 & 0.1 & 1.4 \\
\hline San Juan de los Lagos & 4.1 & 0.0 & 8.5 & 2.7 & 0.0 & 5.7 & 1.4 & 0.0 & 3.0 \\
\hline San Julián & 1.5 & 0.6 & 4.6 & 1.0 & 0.4 & 3.1 & 0.5 & 0.2 & 1.6 \\
\hline San Miguel el Alto & 2.3 & 0.4 & 5.6 & 1.5 & 0.3 & 3.7 & 0.8 & 0.2 & 2.0 \\
\hline Teocaltiche & 6.7 & 4.1 & 11.8 & 4.5 & 2.7 & 7.9 & 2.4 & 1.4 & 4.2 \\
\hline Tepatitlán de Morelos & 1.7 & 0.3 & 5.6 & 1.1 & 0.2 & 3.7 & 0.6 & 0.1 & 2.0 \\
\hline
\end{tabular}

${ }^{a}$ A simulation process was developed to estimate the levels of exposure to arsenic. Calculations were based on the following assumptions: (1) the babies' daily diet included a food formula prepared with $750 \mathrm{~mL}$ of tap water, (2) the children's daily diet included $1000 \mathrm{~mL}$ of tap water, and (3) the adults' daily diet included $1850 \mathrm{~mL}$ of tap water. The mean, minimum, and maximum daily exposure doses to arsenic were estimated by using, respectively, the mean, minimum, and maximum concentrations of total arsenic in drinking water found from the sampling of the wells (Table 1).

mum tolerable concentration of arsenic in drinking water for babies, children, and adults should not be higher than $28.5,42.8$, and $81.0 \mu \mathrm{g} / \mathrm{L}$, respectively. Data from Table 1 indicate that: (1) there are 4 cities where the mean concentration of total arsenic is greater than $28.5 \mu \mathrm{g} / \mathrm{L}$, (2) in 3 cities the mean arsenic concentration is higher than $42.8 \mu \mathrm{g} / \mathrm{L}$, and (3) in just 2 cities the potable water has a mean arsenic concentration over $81.0 \mu \mathrm{g} / \mathrm{L}$. It is important to note that these numbers have a relative value and should be used only as an index. Since each person has his or her own metabolism, an intake above the PTDI does not automatically mean that health is at risk.

There are many cases around the world in which water discharged from wells is directly delivered to a group of houses. Thus, individual calculations for each well (mainly for those wells exceeding standards) and for the group of people who use that well should be performed. As indicated in Table 2, there are 32 wells with a mean total arsenic concentration greater than $28.5 \mu \mathrm{g} / \mathrm{L}, 19$ wells with a mean above $42.8 \mu \mathrm{g} / \mathrm{L}$, and 5 wells with a mean greater than $81.0 \mu \mathrm{g} / \mathrm{L}$.
In addition to the exposure time and the doses to which a person is exposed, sensitivity to the toxic effects of arsenic is different for each individual, and appears to be strongly dependent on the person's nutritional status and genetic characteristics (42). Nevertheless, other factors could play an important role in mitigating the toxic effect of ingested arsenic, such as increased awareness and better education (43). For example, there are some nutrients that can reduce the toxicity of arsenic, such as vitamin $C$ and methionine. In contrast, vitamin A deficiency increases the toxic effects of arsenic (35).

Drinking water over a period of many years with a level of exposure even as low as $1.0 \mu \mathrm{g} / \mathrm{kg} / \mathrm{d}$ has been associated not only with minor skin diseases but also with skin, bladder, kidney, and liver cancer (4). There are many examples from around the world that show the dramatic health effects from ingesting arsenic from groundwater, and the need to motivate health authorities to mitigate this situation. The most striking examples have been in Bangladesh, India (West Bengal), China (Inner Mongolia), and Taiwan $(9,43)$. Unfortunately, so far, no epidemiological studies have been done in the LAJ region to assess the impact of groundwater arsenic on the health of people living there.

In general, most of the epidemiological studies analyze the toxicological effects of ingesting arsenic alone. Nevertheless, drinking water might contain an excess of several chemical elements or compounds, so synergistic and/or antagonistic effects should be considered.

In the case of the LAJ groundwater, there are some aquifers where both arsenic and fluoride exceed Mexican national guideline values. In addition, high levels of fluoride in bottled drinking water sold in the LAJ region have been reported (3). Epidemiological studies performed in the province of Xinjiang, China, have indicated that fluoride and arsenic do not have a mutual synergistic action. However, similar studies done in the province of Guizhou, China, have suggested that the toxicological effects of fluoride could be enhanced by arsenic (44).

Studies from Mexico and many other countries around the world indicate that guideline values (national or international) for both arsenic and flu- 
oride are quite frequently exceeded both in drinking water supplies and in waters that are delivered to the public water system. Presently, arsenic and fluoride are recognized as the most serious inorganic contaminants in drinking water on a worldwide basis (8).

In Mexico only a few epidemiological studies have been done on the health problems due to the ingestion of arsenic from drinking water. Several studies have been done in the Comarca Lagunera region to determine the effect of arsenic on skin cancer and its relation with the human papilloma virus and changes in the immune system (45-47). Levels of arsenic in urine and the accumulation of arsenic in some parts of the body have been determined in the city of Hermosillo, the Valle de Zimapán, and the Valle del Yaqui $(39,48,49)$.

The arsenic concentrations found in well waters in the LAJ region were lower than those reported in some other areas of Mexico, including the Comarca Lagunera, the Valle de Zimapán, and the city of Hermosillo. However, there are many wells in the LAJ region with arsenic levels exceeding both Mexican national standards and international standards, and this situation should be a major concern. Skin diseases, gastrointestinal effects, neurological damage, cardiovascular problems, and hematological effects are some of the potential health effects from chronic arsenic ingestion at the exposure doses estimated for the LAJ region.

Most developed countries have set the guideline value for arsenic in drinking water at $10 \mu \mathrm{g} / \mathrm{L}$, as suggested by the WHO. It is important to note that it is an interim regulation, mainly when there is enough information indicating that potential cancer risks remain high at the present guideline of $10 \mu \mathrm{g} / \mathrm{L}$ (50). It is possible that this standard will be reduced in the near future, as happened in Australia, where the guideline value is $7 \mu \mathrm{g} / \mathrm{L}$ (40). Regulations are a very important in reducing health problems and improving the quality of life. However, there are other associated factors such as the enforcement of the law, the improvement of nutrition programs, and risk communication.

This exhaustive study was the first one ever done that was intended to generate a database on the level of arsenic in groundwater supplies in the LAJ region and to serve as a general indicator of the potential significance of arsenic contamination in the area. Our data set is not large enough to perform detailed analyses regarding health environmental risks. This is due to the lack of information on the level of arsenic in foods, and the lack of epidemiological studies. However, the results produced so far have allowed us to reach five major conclusions concerning additional studies that should be performed in the LAJ region. First, additional physicochemical studies on the arsenic oxidation state in the groundwater are needed to determine the water's level of toxicity and to better understand the process of mobilization and transport of arsenic species. Second, geochemical studies are needed to determine the transport and fate of arsenic in the environment. Third, determining total and inorganic arsenic levels in foods and beverages consumed in the LAJ region might help to better estimate human exposure. Fourth, epidemiological studies to determine the arsenic levels in the blood, hair, and nails of humans should be conducted in the LAJ region, to help assess the relationship between the prevalence of health problems and the chronic ingestion of arsenic. Finally, point-of-use solutions, such as household filters and small treatment plants, should be implemented in the LAJ towns with high levels of arsenic.

Acknowledgements. The authors would like to acknowledge the financial support from El Colegio de la Frontera Norte, A.C., Mexico; the University of Texas at El Paso's Center for Environmental Resource Management through funding from the Office of Exploratory Research of the U.S. Environment Protection Agency (Cooperative Agreement CR-819849-01); and the National Institutes of Health (Grant S06GM8012-33). The authors also thank the Historically Black College and University/Minority Institution Environmental Technology Consortium, which is funded by the U.S. Department of Energy. We also acknowledge the valuable technical support received from the Los Altos de Jalisco water utility authorities, and the logistical support received from Autotransportes Mezcala, S.A.

\section{REFERENCES}

1. México, Instituto Nacional de Estadística, Geografía e Informática. XII Censo General de Población y Vivienda 2000. Aguascalientes: INEGI; 2001.

2. Hurtado R, Gardea-Torresdey J, Tiemann KJ. Fluoride occurrence in tap water at "Los Altos de Jalisco" in the central Mexico region. In: Erickson LE, Rankin MM, eds. Proceedings of the 2000 Conference on Hazardous Waste Research: environmental changes and solutions to resource development, production, and use, 2000 May 23-25, Denver, Colorado. Manhattan: Great Plains/Rocky Mountain
Hazardous Substance Research Center; 2001. Pp. 211-9.

3. Hurtado R, Gardea-Torresdey J. Environmental evaluation of fluoride in drinking water at "Los Altos de Jalisco," in the central Mexico region. J Toxicol Environ Health A. 2004; 67(20-22):1741-53.

4. United States, Agency for Toxic Substances and Disease Registry. Toxicological profile for arsenic. Atlanta: ATSDR, Department of Health and Human Services; 2000.

5. United States, Environmental Protection Agency. Arsenic occurrence in public drink- ing water supplies. Washington, D.C.: EPA; 2000. (Report EPA-815-R-00-023).

6. Thompson TS, Le MD, Kasick AR, Macaulay TJ. Arsenic in well water supplies in Saskatchewan. Bull Environ Contam Toxicol. 1999;63: 478-83.

7. Welch AH, Lico M, Hughes J. Arsenic in ground water of the western United States. Ground Water. 1988;26(3):333-47.

8. Smedley PL, Kinniburgh DG. A review of the source, behavior and distribution of arsenic in natural waters. Appl Geochem. 2002;17: 517-68. 
9. Mandal BK, Suzuki KT. Arsenic round the world: a review. Talanta. 2002;58:201-35.

10. Heinrichs G, Udluft P. Natural arsenic in Triassic rocks: a source of drinking-water contamination in Bavaria, Germany. Hydrogeol J. 1999;7(5):468-76.

11. Hudak PF. Distribution and sources of arsenic in the southern high plains aquifer, Texas, USA. J Environ Sci Health. 2000;A35(6):899913.

12. U.S. Geological Survey. Arsenic. Available from: http://minerals.usgs.gov/minerals / pubs/commodity/arsenic/arsenmcs04.pdf [Web page]. Accessed 22 September 2004. (Mineral Commodity Summaries, January 2004).

13. México, Secretaría de Salud. Modificación a la Norma Oficial Mexicana NOM-127-SSA11994, salud ambiental. Agua para uso y consumo humano. Límites permisibles de calidad y tratamientos a que debe someterse el agua para su potabilización. D Of Fed. 2000;DLXV (13):48-54.

14. World Health Organization. Guidelines for drinking water quality. Vol. 1. Geneva: WHO; 1996.

15. United States, Environmental Protection Agency. National primary drinking water regulations; arsenic and clarifications to compliance and new source contaminants monitoring; final rule. Fed Regist. 2001;66(14):6976-7066.

16. World Health Organization. Environmental health criteria 224: arsenic and arsenic compounds. 2nd ed. Geneva: WHO; 2001.

17. Rosas I, Belmont R, Armienta A, Baez A. Arsenic concentrations in water, soil, milk and forage in Comarca Lagunera, Mexico. Water Air Soil Pollut. 1999;112:133-49.

18. Alarcón Herrera MT, Flores Montenegro I, Romero Navar P, Martín Domínguez IR, Trejo Vázquez R. Contenido de arsénico en el agua potable del valle del Guadiana, México. Ing Hidr Mex. 2001;16:63-70.

19. Armienta MA, Rodriguez R, Aguayo N, Ceniceros N, Villaseñor G, Cruz O. Arsenic contamination of groundwater at Zimapán, Mexico. Hydrogeol J. 1997;5(2):39-46.

20. Wyatt CJ, Fimbres C, Romo L, Méndez RO, Grijalva M. Incidence of heavy metal contamination in water supplies in northern Mexico. Environ Res. 1998;76:114-9.

21. National Research Council. Arsenic in drinking water. Washington, D.C.: National Academy Press; 1999.

22. Hurtado-Jiménez R, Gardea-Torresdey J. Estimación de la exposición a fluoruros en Los Altos de Jalisco, México. Salud Publica Mex. 2005;47:1-6.

23. Aiuppa A, D'Alessandro W, Federico C, Palumbo B, Valenza M. The aquatic geochemistry of arsenic in volcanic groundwaters from southern Italy. Appl Geochem. 2003;18: 1283-96.

24. Lemmo NV, Faust SO, Belton T, Tucker R. Assessment of the chemical and biological significance of arsenical compounds in a heavily contaminated watershed. Part I. The fate and speciation of arsenical compounds in aquatic environments-a literature review. J Environ Sci Health. 1983;A18(3):335-87.
25. Calvo Revuelta C, Álvarez-Benedí J, Andrade Benítez M, Marinero Diez P, Bolado Rodríguez S. Contaminación por arsénico en aguas subterráneas en la provincia de Valladolid: variaciones estacionales. In: Álvarez Benedí J, Marinero P, eds. Estudios de la zona no saturada del suelo. Vol. VI. Valladolid: Instituto Tecnológico Agrario de Castilla y León; 2003. Pp. 91-8.

26. Ballantyne JM, Moore JN. Arsenic geochemistry in geothermal systems. Geochim Cosmochim Acta. 1988;32:475-83.

27. Stüben D, Berner Z, Chandrasekharam D Karmakar J. Arsenic enrichment in groundwater of West Bengal, India: geochemical evidence for mobilization of As under reducing conditions. Appl Geochem. 2003;18:1417-34.

28. Saxena VK, Kumar S, Singh VS. Occurrence, behaviour and speciation of arsenic in groundwater. Curr Sci. 2004;86(2):281-4.

29. México, Instituto Nacional de Estadística, Geografía e Informática. Estudio hidrológico del estado de Jalisco. Aguascalientes: INEGI; 2000.

30. Das HK, Mitra AK, Sengupta PK, Hossain A, Islan F, Rabbani GH. Arsenic concentration in rice, vegetables, and fish in Bangladesh: a preliminary study. Environ Intern. 2004;30:383-7.

31. Queirolo F, Stegen S, Restovic M, Paz M, Ostapczuk P, Schwuger M, et al. Total arsenic, lead, and cadmium levels in vegetables cultivated at the Andean villages of northern Chile. Sci Total Environ. 2000;255:75-84.

32. Tao SSH, Bolger PM. Dietary arsenic intakes in the United States: FDA total diet study, September 1991-December 1996. Food Addit Contam. 1998;16(11):465-72.

33. Sapunar-Postruznik J, Bazulie D, Kubala H. Estimation of dietary intake of arsenic in the general population of the Republic of Croatia. Sci Total Environ. 1996;191:119-23.

34. Schoof RA, Yost LJ, Eickhoff J, Crecelius EA, Cragin DW, Meacher DM, et al. A market basket survey of inorganic arsenic in food. Food Chem Toxicol. 1999;37:839-46.

35. Roychowdhury T, Tokunaga H, Ando M. Survey of arsenic and other heavy metals in food composites and drinking water and estimation of dietary intake by the villagers from an arsenic-affected area of West Bengal, India. Sci Total Environ. 2003;308:15-35.

36. Llobet JM, Falcó G, Casas C, Teixidó A, Domingo JL. Concentrations of arsenic, cadmium, mercury, and lead in common foods and estimated daily intake by children, adolescents, adults, and seniors of Catalonia, Spain. J Agric Food Chem. 2003;51:838-42.

37. Delgado-Andrade C, Navarro M, López $H$, López MC. Determination of total arsenic levels by hydride generation atomic absorption spectrometry in foods from south-east Spain: estimation of daily dietary intake. Food Addit Contam. 2003;20(10):923-32.

38. Del Razo LM, Garcia-Vargas GG, GarciaSalcedo J, Sanmiguel MF, Rivera M, Hernandez MC, et al. Arsenic levels in cooked food and assessment of adult dietary intake of arsenic in the Region Lagunera, Mexico. Food Chem Toxicol. 2002;40:1423-31.
39. Meza MM, Kopplin MJ, Burgess JL, Gandolfi AJ. Arsenic drinking water exposure and urinary excretion among adults in the Yaqui Valley, Sonora, Mexico. Environ Res. 2004;96: 119-26.

40. Health Canada. Arsenic in drinking water. Available from: http://www.hc-sc.gc.ca/ hecs-sesc/water/pdf/arsenic_drinking water.pdf [Web page]. Accessed 2 February 2005. (Document Arsenic (11/04)).

41. The Food and Agriculture Organization/ World Health Organization, Expert Committee on Food Additives. Evaluation of certain food additives and contaminants. Geneva: WHO; 1989. (Technical Report Series 776).

42. Anawar H, Akai J, Mostofa KMG, Safiullah S Tareq SM. Arsenic poisoning in groundwater: health risk and geochemical sources in Bangladesh. Enivron Int. 2002;27:597-604.

43. Chakraborti D, Rahman MM, Paul K, Chowdhury UK, Sengupta MK, Lodh D, et al. Arsenic calamity in the Indian subcontinent. What lessons have been learned? Talanta. 2002;58:3-22.

44. Zheng Y, Wu J, Ng JC, Wang G, Lian W. The absorption and excretion of fluoride and arsenic in humans. Toxicol Lett. 2002;133:77-82.

45. Salazar AM, Calderón-Aranda E, Cebrián ME, Sordo M, Bendesky A, Gómez-Muñoz A, et al. p53 expression in circulating lymphocytes of non-melanoma skin cancer patients from an arsenic contaminated region in Mexico. A pilot study. Mol Cell Biochem. 2004;255: 25-31.

46. Rosales-Castillo JA, Acosta-Saavedra LC, Torres R, Ochoa-Fierro J, Borja-Aburto VH, Lopez-Carrillo L, et al. Arsenic exposure and human papillomavirus response in nonmelanoma skin cancer Mexican patients: a pilot study. Int Arch Occup Environ Health. 2004;77;418-23.

47. Pineda-Zavaleta AP, García-Vargas G, BorjaAburto VH, Acosta-Saavedra LC, Vera Aguilar E, Gómez-Muñoz A, et al. Nitric oxide and superoxide anion production in monocytes from children exposed to arsenic and lead in region Lagunera, Mexico. Toxicol Appl Pharmacol. 2004;198:283-90.

48. Wyatt CJ, Quiroga VL, Olivas Acosta RT, Méndez RO. Excretion of arsenic (As) in urine of children, 7-11 years, exposed to elevated levels of As in the city water supply in Hermosillo, Sonora, México. Environ Res. 1998; 78:19-24.

49. Armienta MA, Rodríguez R, Cruz O. Arsenic content in hair of people exposed to natural arsenic polluted groundwater at Zimapán, México. Bull Environ Contam Toxicol. 1997; 59:583-9.

50. National Research Council. Arsenic in drinking water: 2001 update. Washington, D.C.: National Academy Press; 2001.

Manuscript received 4 March 2005. Revised manuscript accepted for publication 11 January 2006. 
RESUMEN Objetivos. Determinar el grado de contaminación con arsénico del agua potable en la región de Los Altos de Jalisco (LAJ), en la parte centrooccidental de México, y estimar el nivel de exposición que enfrentan los habitantes de esa zona.

\section{Arsénico en el agua potable de la región de Los Altos de Jalisco, México}

Palabras clave Arsénico, abastecimiento de agua, contaminantes del agua, México.
Métodos. Se determinó la concentración total de arsénico (la suma de todas las formas de arsénico, tanto orgánicas como inorgánicas) en 129 pozos de agua públicos en 17 cabeceras municipales de LAJ, mediante espectroscopia de emisión óptica con plasma inductivamente acoplado. En la mayoría de los pozos se tomaron muestras en noviembre de 2002 y en octubre de 2003. En los restantes se tomó la muestra en uno de esos dos momentos. El nivel de exposición al arsénico se estimó para lactantes $(10 \mathrm{~kg})$, niños $(20 \mathrm{~kg})$ y adultos $(70 \mathrm{~kg})$.

Resultados. En 44 (34\%) de los 129 pozos se encontraron concentraciones media de arsénico superiores al límite de $25 \mu \mathrm{g} / \mathrm{L}$, establecido en la norma nacional mexicana. Las concentraciones media de arsénico total en los 129 pozos estuvieron entre 14,7 $\mu \mathrm{g} / \mathrm{L}$ y $101,9 \mu \mathrm{g} / \mathrm{L}$. Las mayores concentraciones se encontraron en las muestras de agua colectadas en los pozos de Mexticacán $(262,9 \mu \mathrm{g} / \mathrm{L})$, Teocaltiche $(157,7 \mu \mathrm{g} / \mathrm{L})$ y San Juan de los Lagos (113,8 $\mu \mathrm{g} / \mathrm{L})$. Si se toma en cuenta la concentración general de todos los pozos de cada una de las 17 ciudades, la concentración media de arsénico fue superior a lo establecido en la norma mexicana en 7 ciudades. La concentración media general en las 17 ciudades fue superior al valor de $10 \mu \mathrm{g} / \mathrm{L}$ establecido en los lineamientos de la Organización Mundial de la Salud. Los niveles estimados de las dosis de exposición al arsénico por el agua potable fue de $1,1-7,6 \mu \mathrm{g} / \mathrm{kg} / \mathrm{d}$ en los lactantes, de $0,7-5,1 \mu \mathrm{g} / \mathrm{kg} / \mathrm{d}$ en los niños y de $0,4-2,7 \mu \mathrm{g} / \mathrm{kg} / \mathrm{d}$ en los adultos.

Conclusiones. Según la dosis de exposición estimada en la región de LAJ, la ingestión continuada de arsénico puede afectar a la salud y causar enfermedades de la piel, trastornos gastrointestinales, daños neurológicos, problemas cardiovasculares y afecciones hematológicas. Aunque esta situación no afecte a todos los habitantes, la salud de una gran parte de la población de LAJ puede encontrarse en riesgo debido a la ingestión de cantidades elevadas de arsénico. Se deben realizar estudios epidemiológicos para determinar el contenido de arsénico en la sangre, el pelo y las uñas de las personas que viven en la región de LAJ, a fin de ayudar a evaluar la relación entre la prevalencia de problemas de salud y la ingestión continuada de arsénico.

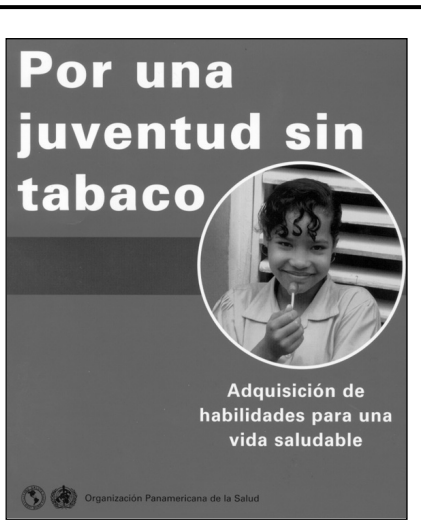

2001, 72p.,

ISBN 9275315795

Código: PC 579

Precios: US\$ 14.00 en

América Latina/ US\$ 18.00

en el resto del mundo

\section{Por una juventud sin tabaco}

En la primera parte del libro se muestran los problemas fundamentales del consumo de tabaco, especialmente para la juventud. Se revisan temas relacionados con la prevención de las enfermedades relacionadas con el tabaco en los países de la Región y se describen los aspectos más eficaces de los diferentes métodos usados para su prevención. En la segunda, se presentan los enfoques teóricos y prácticos del programa de prevención del hábito de fumar conocido como "Habilidades para la vida", que alecciona a los jóvenes para que sean capaces de resistir las presiones sociales y de los medios de comunicación que los incitan a fumar.

Esta publicación está destinada a los profesionales de la salud, los planificadores de programas, los educadores, los encargados de formular las políticas y los grupos e instituciones que participan en la lucha contra el tabaquismo. En ella encontrarán información muy útil sobre la situación del tabaquismo en la Región, así como pautas para planificar y desarrollar programas de prevención del abuso de drogas, similares al de "Habilidades para la vida", que se adapten a las necesidades específicas de la Región y que sean un arma poderosa para la reducción de la carga evitable de muertes y discapacidades relacionadas con el tabaco. 